\title{
A Review on Top-Down and Bottom-Up Approach for Air Pollution Studies
}

\author{
Abulude, F. O. ${ }^{1, *}$, Bahloul, M. ${ }^{2}$, Adeoya, E. A. ${ }^{3}$ and Olubayode, S. A. ${ }^{3,4}$ \\ ${ }^{1}$ Science and Education Development Institute, Akure, Ondo State, Nigeria \\ ${ }^{2}$ Unité de recherche Etude et Gestion des Environnements Côtiers et Urbains, Faculté des \\ Sciences de Sfax, Université de Sfax, BP 1171, 3000 Sfax, Tunisia; bahloulmoez_grn@yahoo.fr \\ ${ }^{3}$ Engineering Materials Development Institute, Akure, Ondo State, Nigeria; \\ adeoya@yahoo.com (A.E.A.); smart@yahoo.com (O.S.A.) \\ ${ }^{4}$ Department of Civil Engineering, University of Agriculture, Abeokuta, Ogun State, Nigeria \\ *Corresponding author: waleabul@yahoo.com or samuel.fagbayide@federalpolyilaro.edu.ng
}

\begin{abstract}
No doubt pollution is a global problem which must be holistically tackled. In doing this, adequate knowledge of the sources of pollution is important, therefore the aim of this paper is to review source apportionment with reference to top-down and bottom-up methods. In this paper, dispersion modeling, emissions inventory, and sampling methods were discussed. Also, analytical methods involved in top-down source apportionment were mentioned. The two techniques are needed to evaluate pollutants and their sources. Based on these two approaches, pollution control strategy would be developed and decisions can be made in deciding the right approach to solve or reduce the pollution problems.
\end{abstract}

Keywords: PM10, TSP, Pollutants, Element markers, Epidemiological, Dispersion modeling

\section{INTRODUCTION}

Air quality has gained a lot of attention in developing and developed countries of the world due to the impacts on man, animals, and materials. These impacts depend on the pollutant type, its concentration in air, length of exposure, other pollutants in the air, and individual susceptibility (Pope and Dockery, 2006). Epidemiological studies by Health Effect Institute, (2004) and have shown that ambient particulate matter (PM) levels lead to an increased risk of mortality and morbidity.

PM is one of the problematic pollutants of concern in Europe and other continents (Harrison et al., 2008). The classification of the particles in the air are done by size and chemical composition, these are known as PM or aerosols. The different sizes of aerosols are:

* Total Suspended Particulates (TSP, with aerodynamic diameter $<\sim 30$ microns $(\mu \mathrm{m})$ 
* $\quad \mathrm{PM}_{10}$ (with an aerodynamic diameter of less than $10 \mu \mathrm{m}$ also referred to as coarse).

* $\quad \mathrm{PM}_{2.5}$ (with an aerodynamic diameter of less than $2.5 \mu \mathrm{m}$ also referred to as fine).

* Ultrafine PM is that with a diameter of fewer than 0.1 microns.

Few of the particles could originate from volcanoes, dust storms, forest and grassland fires, living vegetation, sea spray and human activities like industrial emissions and land use change (Guttikunda, 2008). The sizes of PM affect the atmospheric lifetime, spatial distributions, indooroutdoor ratios, variability and wealth impacts of particles.

Aerosol in terms of mechanisms of emissions are classified as Primary and Secondary particles emitted directly from sources like burning, road traffic, windblown soil, industrial activities, carbon, organic compounds, metal, and metal oxides and ions into the atmosphere, while secondary particles are through the chemical transformation of gaseous. Volatile organic compounds (VOC's), Sulphur Dioxide $\left(\mathrm{S}_{2}\right)$, Ammonia $\left(\mathrm{NH}_{3}\right)$, Nitrogen Oxides $(\mathrm{NOx})$ are the organic pollutants.

\section{Composition and Metal Emission Sources}

According to Chow (1995), the major compositions of PM mass are:

1. Geological matters (oxides of $\mathrm{Al}, \mathrm{Si}, \mathrm{Ca}, \mathrm{T}, \& \mathrm{Fe}$ )

2. Organic matter/carbon (OC - Consisting of hundreds of different compounds)

3. Elemental Carbon (EC)

4. Sulphates

5. Nitrates

6. Ammonium

In addition, liquid water absorbed by water-soluble species 
Table 1: Emission source and element markers

\begin{tabular}{|c|c|c|}
\hline \multirow{2}{*}{$\begin{array}{l}\text { Emission Source } \\
\text { Soil }\end{array}$} & & \multirow{2}{*}{$\begin{array}{l}\text { Marker Elements } \\
\mathrm{Al}, \mathrm{Si}, \mathrm{Sc}, \mathrm{Ti}, \mathrm{Fe}, \mathrm{Sm}, \mathrm{Ca}\end{array}$} \\
\hline & - & \\
\hline Road dust & - & $\mathrm{Ca}, \mathrm{Al}, \mathrm{Sc}, \mathrm{Si}, \mathrm{Ti}, \mathrm{Fe}, \mathrm{Sm}$ \\
\hline Sea Salt & - & $\mathrm{Na}, \mathrm{Cl}, \mathrm{Na}^{+}, \mathrm{Cl}^{-}, \mathrm{Br}, \mathrm{I}, \mathrm{Mg}, \mathrm{Mg}^{2+}$ \\
\hline Oil burning & - & $\mathrm{V}, \mathrm{Ni}, \mathrm{Mn}, \mathrm{Fe}, \mathrm{Cr}, \mathrm{As}, \mathrm{S}, \mathrm{SO}^{2-}$ \\
\hline Coal burning & - & Al, Sc, Se, Co, As, Ti, Th, S \\
\hline Iron and Steel industric & $\mathrm{s}-$ & $\mathrm{Mn}, \mathrm{Cr}, \mathrm{Fe}, \mathrm{Zn}, \mathrm{W}, \mathrm{Rb}$ \\
\hline Non-ferrous metal ind & Istries - & $\mathrm{Zn}, \mathrm{Cu}, \mathrm{As}, \mathrm{Sb}, \mathrm{Pb}, \mathrm{Al}$ \\
\hline Glass industry & - & $\mathrm{Sb}, \mathrm{As} \mathrm{Pb}$ \\
\hline Cement industry & - & $\mathrm{Ca}$ \\
\hline Refuse incineration & - & $\mathrm{K}, \mathrm{Zn}, \mathrm{Pb}, \mathrm{Sb}$ \\
\hline Biomass burning & - & $\mathrm{K}, \mathrm{C}_{\text {ele }}, \mathrm{C}_{\text {org }}, \mathrm{Br}, \mathrm{Zn}$ \\
\hline Automobile gasoline & - & $\mathrm{C}_{\text {ele }}, \mathrm{Br}, \mathrm{Ce}, \mathrm{La}, \mathrm{Pt}, \mathrm{SO}_{4}^{2-,} \mathrm{NO}_{3}^{-}$ \\
\hline Secondary aerosol & - & $\mathrm{SO}_{4}^{2-,} \mathrm{NO}_{3}{ }^{-}, \mathrm{NH}_{4}^{+}$ \\
\hline
\end{tabular}

Source: Guttikunda (2008) * Marker elements are arranged by priority order

Table 1 is source markers associated with various emission sources. Source markers are such that are abundant in one source types but are minimally present in other source types. When a source has a chemical marker, it is easy to identify the dominant source, and receptor modeling helps to estimate the contribution of these sources based on factor analysis. Bellis et al. (2014) has categorized four main sources in Europe as:

(i) Traffic, (ii) Mineral/Crustal matter, (iii) Sea-salt, Sea-spray, and marine and

(iv) Regional-scale pollution and long-range transboundry anthropogenic pollution. 


\section{APPORTIONMENT OF PARTICULATE POLLUTION}

In recent times particulate pollution is being a big area of concern in the field of air pollution, information is required on sources of pollution and their contribution to the ambient levels of pollution. To know how to reduce pollution in the environment, there is the need to conduct a source appointment study which will inform what the sources of pollution are and how much each source contributes to total pollution.

The two techniques (Fig 1) used to evaluate pollution sources are:

1. Top-Down or Receptor-based modeling methods

2. Bottom-up method or source-based modeling methods

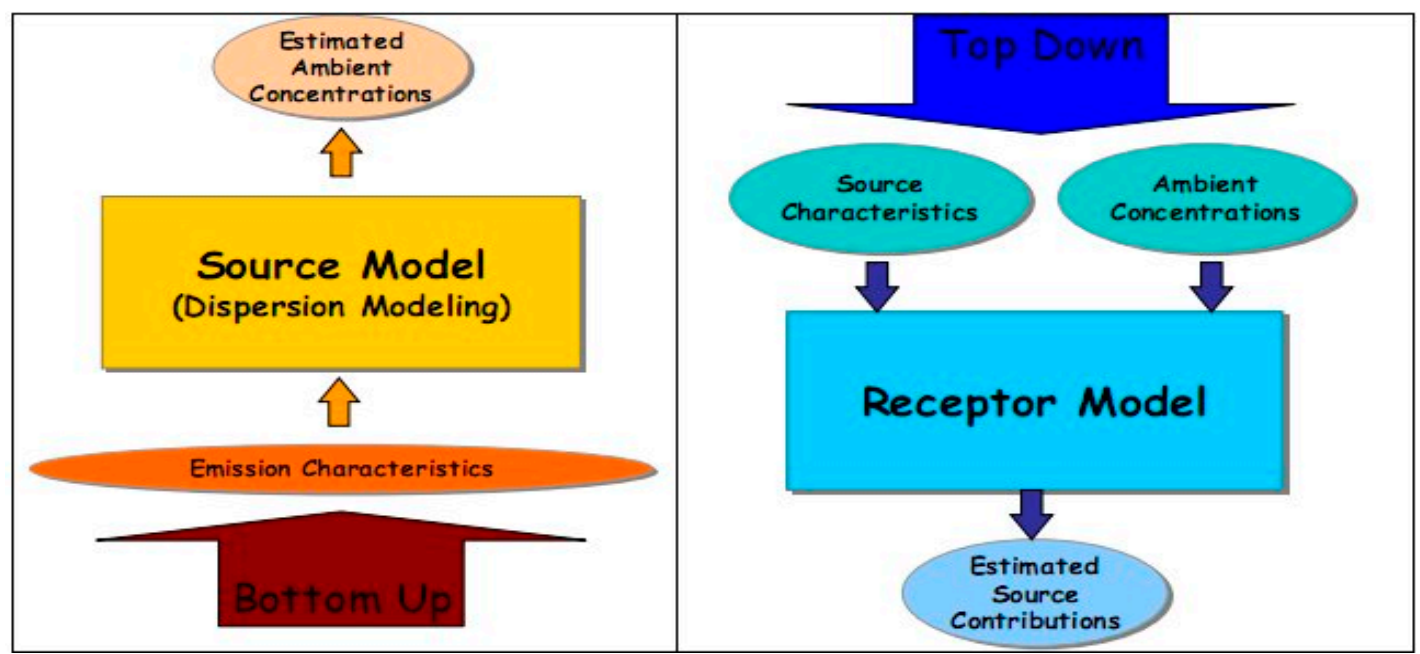

Source: Guttikunda (2011).

Fig 1: Bottom - up and Top - down source apportionment.

\section{TOP-DOWN MODELING METHOD}

This method starts by monitoring the ambient pollution through the generation of data, thereafter utilizing models to relate measurements to specific sources of pollutants through chemical analysis of the samples. Top-down methods complement bottom-up methods. This method is applied for particulate pollution only. Fig 2 presents an outline of steps needed to use a source apportionment in a study area especially urban area. 


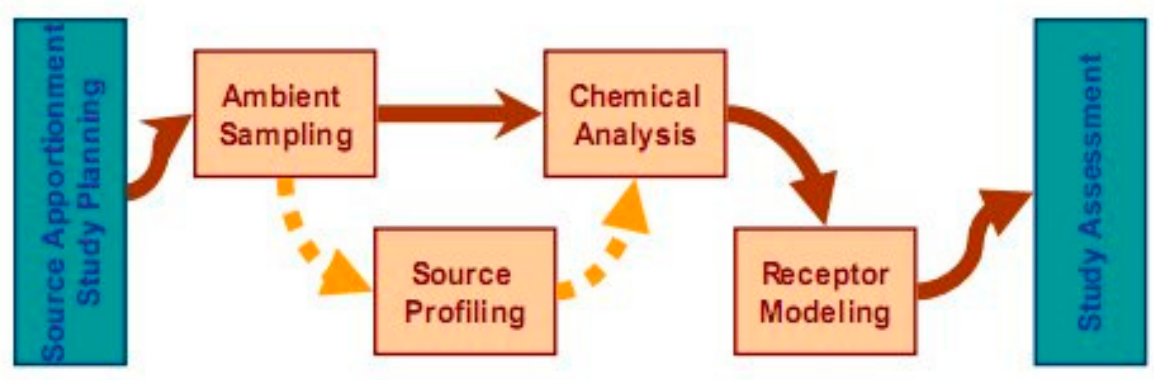

Source: Guttikunda (2011)

Fig 2: Top-down source apportionment study

Top-down analysis requires real-world measurement and knowledge of potential sources compared to bottom-up analysis which requires knowledge of source and source strengths as well as information on meteorology and local conditions.

\section{BOTTOM - UP MODELING METHOD}

This modeling method utilizes sector - specific and technical emission factors in the construction of PM emission inventories. It must be noted that an accurate emission inventory is an important part of an air quality management system which can provide policymakers with reliable information on air pollution.

In air quality models emission inventories are used as inputs which can be used to evaluate control strategies. It is paramount to quantify the accuracy and degree of representation of any inventory. There are no simple formulas when developing an emission inventory (Johnson et al., 2011).

Atmospheric models of dispersion, transport, and chemistry utilize information from emissions inventories to predict concentrations of air pollutants in the air. In doing so, it is necessary to resolve emission inventories in space and time and allocate emissions to specific locations. With this model, the PM pollution contributions from different sources can be quantified.

A Bottom-up modeling method (Fig 3) quantifies pollution based on the distribution of pollution causing activities in a city. It is an important idea if all cities establish an emission inventory baseline this would be useful for air pollution policy-related action plans (Guttikunda, 2011). A 
basic inventory can be developed using available information. According to Guttikunda (2011), various pollution-causing activities would be mapped out first, then each of the sources to quantify energy usage and emission would be zero.

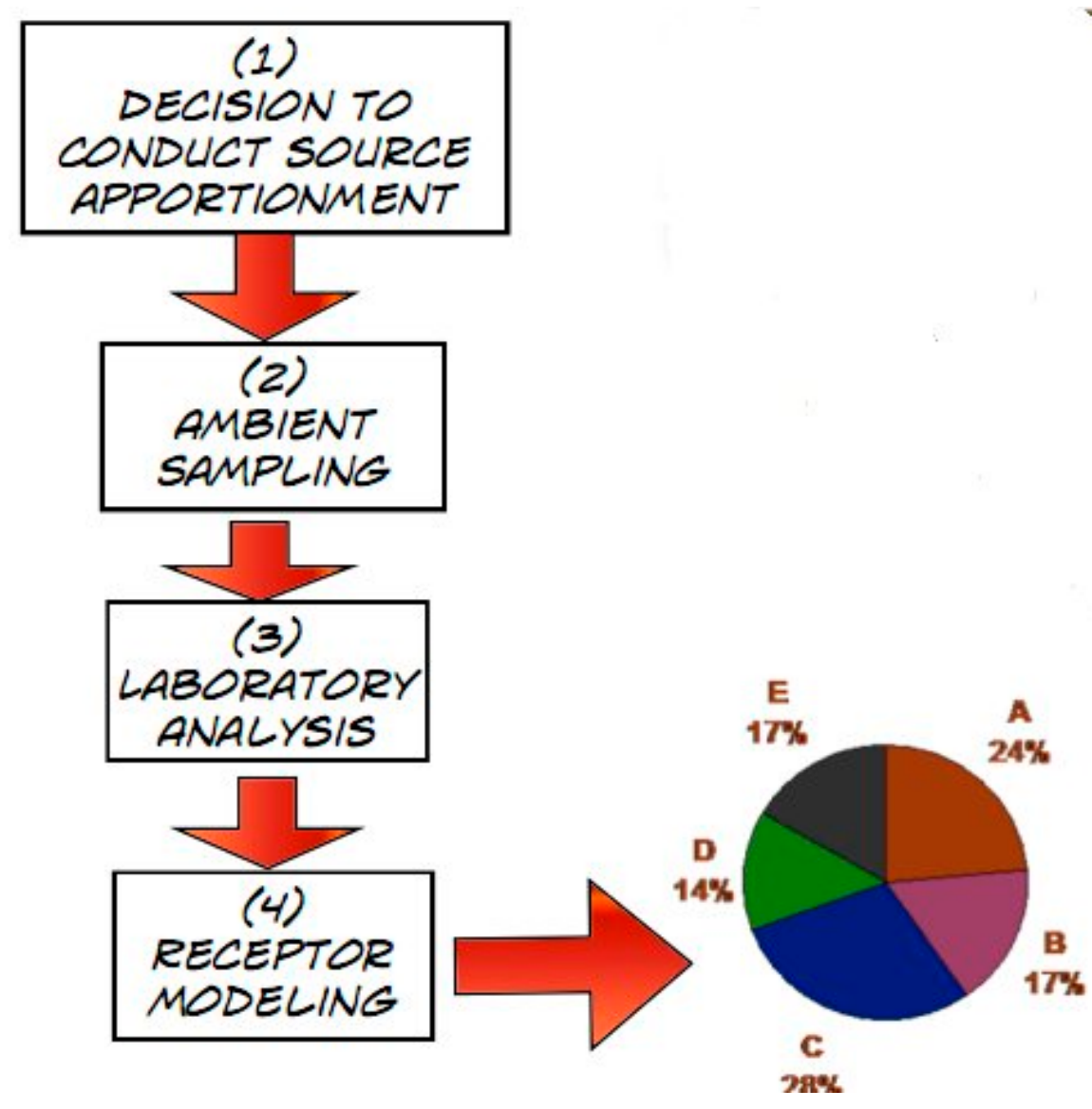

Source: Guttikunda (2011)

Fig 3: Bottom - up modeling method

\section{EMISSIONS INVENTORY}

An emission inventory is not directly utilized in a top-down analysis, it essential in the quantification of source strengths and identification of source profile to assist in efficient and effective receptor modeling. Emission inventory will help in the determination of the area to locate receptors and also the determination of the area of possible hot spots. 
To create emissions inventory, the activity data needed are the compilation of industrial energy consumption through audits and energy statistics, determine vehicle statistics from the transport census for vehicle miles traveled, determine also the domestic sector to obtain a sense of energy used at the household level. Later existing emission factors to calculate emissions by sector can then be used. At the end of gathering data input in energy used by sector, then existing emission factor can then be used for the calculation.

\section{Emissions $=$ Emission Factor $\mathrm{x}$ Energy}

Emission factor unit of pollution released per unit of energy consumed.

If per adventure emission factor of the city is not available, the existing emission factor of the city from the literature can be employed in the calculation. The reason for this is that emission factors do not vary depending on the combustion technologies in use within the city. A schematic diagram in Fig 4 depicts the determination of an emissions inventory in a city.

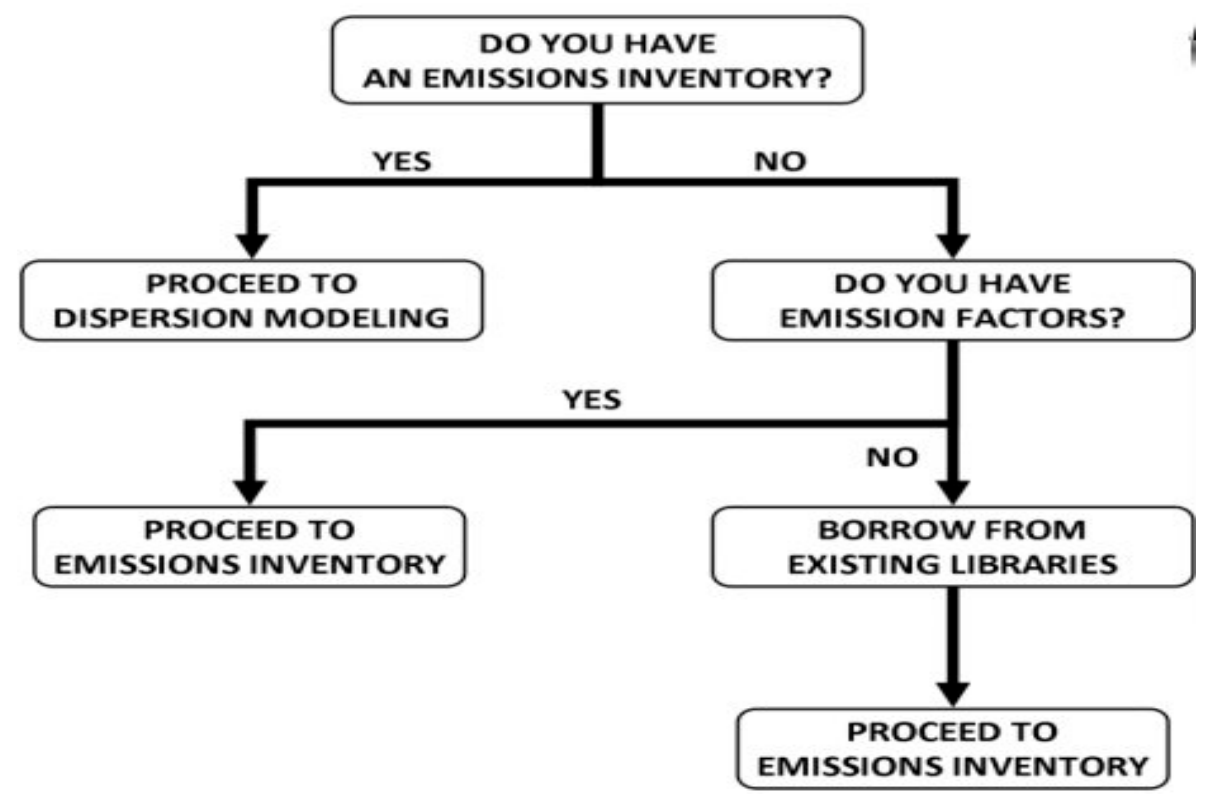

Fig 4: An emission inventory

Source: Guttikunda (2011).

In emissions inventory, the particulate samples provide the contributions of various sources in percentage likewise the percentage contributions from the top-down method of analysis. The results obtained from the two methods are not alike, the results from emissions inventory provide 
the weight of pollution from various sources (mass/year) whereas, the top-down methodology provides the source contributions to the ambient concentrations of mass per volume.

The results of emissions inventory and that of top-down study can be compared by converting the emissions into ambient concentration when a dispersion model is used.

It must be noted that the types of sources influence ambient concentrations. For example a power plant releasing a lot of pollution contributions less to the immediate environment due to long range transport, while for example, ground level emissions from vehicle exhaust, though a small percent in the inventory have a disproportionately larger share in the local concentrating (Guttikunda, 2011).

\section{DISPERSION MODELING}

When using this dispersion model, it should be noted that physical and meteorological conditions have an important role to play. A pollutant emission rate and meteorological information are imputed to a mathematical model that disperses the emitted pollutant where the pollutants may also chemically transform, generating a prediction of the resulting pollutant concentration at a point in space and time (Chowdhury et al., 2009). Topographical features and certain seasonal features can affect the air pollution concentrations, for example in urban environs with the temperate and cold weather, there is the possibility to feel seasonality in their pollution patterns due to the increased fuel usage for their heating during the winter months.

\section{Advantages of bottom - up methods}

1. Locating pollution sources through the development of emission inventories.

2. It is useful for the identification of potential sources of primary emissions

3. It can describe the relevant physical properties that affect the ambient levels (terrain, meteorological features).

4. It makes understanding the chemical processes that influence local pollutant levels including the formation of secondary aerosols easy.

5. It assists in documenting the potential for secondary aerosol formation. 
6. It identifies sources that would be most effective in controlling and affecting the ambient compliance level the most.

7. Allows a direct estimate of the effect of changes in emissions on ambient pollutant concentrations, through emission control simulations.

8. Provision of spatial coverage of how sources impact air quality and exposure.

Source: Johnson et al., (2011).

\section{Reconciling Results}

Top - down results can be used to correct the missing sources in the emissions inventory sources in the emissions inventory.

The dispersion modeling results can assist to identify the pollution hot spots in the city, where sampling for the top-down approach can be performed (Owoade et al., 2016).

Monitoring of data can assist in validating the results of dispersion modeling can be further expanded for evaluation of "what if" emission scenarios.

Altogether, both methods provide a strong resource for developing a pollution central strategy.

\section{AMBIENT SAMPLING}

Selection of sampling sites, suitable sampler and size range and a filter is paramount. These depend on the chemical analyses one has in mind. When selecting sites, the topography, number of samples to collected areas, meteorological instrument, space, accessibility, power, and security should be taken into consideration.

The choice of selecting a sampler will depend on the size range of particles and the method of chemical analyses. Examples of aerosol samplers are: Hi-volume, medium - volume, low-volume dichotomous sampler, mini-volume samplers. They have different descriptions, particle size $(\mu \mathrm{m})$ and flow rate $(1 / \mathrm{mm})$ (Khan et al., 2015). Commonly used filters matrices are pure quartz, coated quartz and teflon, nylon, poly carbonate glass fibre and cellulose esters (Bellis et al., 2014). 
According to Belis et al., (2014), only quartz fibre filters are suitable for the determination of irons, elements and carbonaceous fractions.

\section{Source Profiling}

A source profile identifies the quantities of specific air pollutants (elements and ions) released from individual sources (Fawole et al., 2016). Likewise, it provides important data used for source apportionment as these determine the next level of assessment and provide the basis for estimating. The more accurate a source profile is, the more likely that quality results will follow. A source profile is a key to linking samples with sources.

Source profiles are likely to contain a wide range of element, ions, carbon fractions, organic compounds, isotopic abundances, particle size distributions, and shapes. A source has a marker to be able to identify the dominant source, while receptor modeling assists to quantify the contributions of these sources based on factor analysis (Morales and Nenes (2014).

Organic marker compounds have become more useful as many toxic elements formally used as markers are removed from emission sources ( $\mathrm{Pb}$ from gasoline engine exhaust). 
Table 2: Elements and Possible Sources.

\begin{tabular}{ll}
\hline Elements & \multicolumn{1}{c}{ Source Marker } \\
\hline $\mathrm{Al}, \mathrm{Si}, \mathrm{Ca}, \mathrm{Ti}, \mathrm{Mn}$ & Soils, Dust \\
$\mathrm{S}$ & Fossil fuels, anthropogenic and biomass burning, Oceans, \\
& Soil erosion. \\
$\mathrm{Cl}$ & CFC's, Soil, Sea Salt and Anthropogenic sources \\
$\mathrm{K}$ & Coal Combustion, Biomass burning, Biomass fuels \\
$\mathrm{C}$ & Fuel oil and steel factories \\
$\mathrm{Cr}$ & Emissions from chemical plants, Cement dust and Crustal \\
& Sources. \\
$\mathrm{Fe}$ & Soils, Smelting industry \\
$\mathrm{Ni}$ & Heavy fuel oil combustion \\
$\mathrm{Cu}$ & Industries and Waste treatment \\
$\mathrm{Zn}$ & Combustion of coal and heavy fuel oil \\
$\mathrm{As}$ & Solid mineral fuels, heavy fuel oil, Volcanoes, Smelting industry \\
$\mathrm{Se}$ & Heavy fuel oil and glass production \\
$\mathrm{Br}$ & Gasoline, transportation industry \\
$\mathrm{Rb}$ & Crustal Sources \\
$\mathrm{Pb}$ & Paint industry, leaded fuel use \\
\hline
\end{tabular}

Source: Johnson et al. (2011). 
Table 3: Elements, Conic and Carbon source markers

\begin{tabular}{llllll}
\hline Source type & Dominant & $<0.1 \%$ & 0.1 to $1 \%$ & 1 to $10 \%$ & $>10 \%$ \\
& Particle size & & & \\
\hline
\end{tabular}

\begin{tabular}{|c|c|c|c|c|}
\hline Paved Road & Coarse (2.5 & $\mathrm{Cr}, \mathrm{Sr}, \mathrm{Pb}, \mathrm{Zr}$ & $\mathrm{S} 04^{2--} \mathrm{Na}^{+}, \mathrm{K}^{+}, \mathrm{P}$ & $\mathrm{Ec},, \mathrm{Al}, \mathrm{K}, \mathrm{Ca}$ \\
\hline & to $10 \mu \mathrm{m})$ & & $\mathrm{S}, \mathrm{Cl}, \mathrm{Mn}, \mathrm{Ba}, \mathrm{Ti}$ & $\mathrm{Fe}$ \\
\hline
\end{tabular}

$\begin{array}{lrrcc}\text { Unpaved Road Coarse } & \mathrm{NO}_{3}{ }^{-}, \mathrm{NH}_{4}{ }^{+}, \mathrm{P} & \mathrm{SO}_{4}{ }^{2-}, \mathrm{Na}^{+}, \mathrm{K}^{+}, \mathrm{P}, \mathrm{S} & \mathrm{Oc}, \mathrm{Al}, \mathrm{K}, \mathrm{Ca} & \mathrm{Si} \\ \text { Dust } & \mathrm{Zn}, \mathrm{Sr}, \mathrm{Ba} & \mathrm{Cl}, \mathrm{Mn}, \mathrm{Ba}, \mathrm{Ti} & \mathrm{Fe} & \end{array}$

Construction Coarse $\quad \mathrm{Cr}, \mathrm{Mn}, \mathrm{Zn}, \mathrm{Sr} \quad \mathrm{SO}_{4}{ }^{2-}, \mathrm{Na}+, \mathrm{K}+, \mathrm{S} \quad \mathrm{Oc}, \mathrm{Al}, \mathrm{K}, \mathrm{Ca} \quad \mathrm{Si}$

$\mathrm{Ba} \quad \mathrm{Fe}$

\begin{tabular}{|c|c|c|c|c|c|}
\hline Agriculture & Coarse & $\mathrm{NO}_{3}{ }^{-}, \mathrm{NH}_{4}{ }^{+}, \mathrm{Cr}$ & $\mathrm{SO}_{4}{ }^{2--} \mathrm{Na}^{+}, \mathrm{K}^{+}, \mathrm{S}$ & $\mathrm{Oc}, \mathrm{Al}, \mathrm{K}, \mathrm{Ca}$ & \\
\hline Soil & & $\mathrm{Zn}, \mathrm{Sr}$ & $\mathrm{Cl}, \mathrm{Mn}, \mathrm{Ba}, \mathrm{Ti}$ & $\mathrm{Fe}$ & $\mathrm{Si}$ \\
\hline Natural Soil & Coarse & $\begin{array}{l}\mathrm{Cr}, \mathrm{Mn}, \mathrm{Sr}, \mathrm{Zn} \\
\mathrm{Ba}\end{array}$ & $\begin{array}{l}\mathrm{Cl}-, \mathrm{Na}^{+} \mathrm{Ec}, \mathrm{P} \\
\mathrm{S}, \mathrm{Cl}, \mathrm{Ti}\end{array}$ & $\begin{array}{l}\mathrm{OC}, \mathrm{Al}, \mathrm{Mg}, \mathrm{K} \\
\mathrm{Ca}, \mathrm{Fe}\end{array}$ & $\mathrm{Si}$ \\
\hline Lake Bed & Coarse & $\mathrm{Mn}, \mathrm{Sr}, \mathrm{Ba}$ & $\mathrm{K}^{+}, \mathrm{Ti}$ & $\begin{array}{c}\mathrm{SO}_{4}{ }^{2-}, \mathrm{Na}^{+}, \mathrm{Oc}, \mathrm{Al} \\
\mathrm{S}, \mathrm{Cl}, \mathrm{K} ; \mathrm{Ca}, \mathrm{Se}\end{array}$ & $\mathrm{Si}$ \\
\hline Motor & Fine $(\mathrm{V}-$ & $\mathrm{Cr}, \mathrm{NiY}, \mathrm{Sr}$ & $\mathrm{Si}, \mathrm{Cl}, \mathrm{Al}, \mathrm{Si}, \mathrm{P}$ & $\mathrm{Cl}, \mathrm{NO}_{3}^{-}, \mathrm{SO}_{4}{ }^{2-}$ & $\mathrm{Oc}, \mathrm{Ec}$ \\
\hline Vehicle & $2.5 \mu \mathrm{m})$ & $\mathrm{Ba}$ & $\begin{array}{c}\mathrm{Ca}, \mathrm{Mn}, \mathrm{Fe}, \mathrm{Zn} \\
\mathrm{Br}, \mathrm{Pb}\end{array}$ & $\mathrm{NH}_{4}{ }^{+}, \mathrm{S}$ & \\
\hline
\end{tabular}

Vegetative Fine $\quad \mathrm{Ca}, \mathrm{Mn}, \mathrm{Fe}, \mathrm{Zn} \quad \mathrm{NO}_{3}{ }^{-}, \mathrm{SO}_{4}{ }^{2-}, \mathrm{NH}_{4}{ }^{+} \quad \mathrm{Cl}^{-}, \mathrm{K}^{+}, \mathrm{Cl}, \quad \mathrm{Oc}$, Ec

Burning $\mathrm{Br}, \mathrm{Rb}, \mathrm{Pb} \quad \mathrm{Na}^{+}, \mathrm{S} \quad \mathrm{K}$

Residual oil Fine $\quad \mathrm{K}^{+}, \mathrm{Oc}, \mathrm{Cl}, \mathrm{Ti}, \mathrm{Cr} \quad \mathrm{NH}_{4}{ }^{+}, \mathrm{Na}^{+}, \mathrm{Zn}, \mathrm{Fe} \quad \mathrm{V}, \mathrm{Oc}, \mathrm{Ec}, \quad \mathrm{S}, \mathrm{SO}_{4}{ }^{2-}$ 


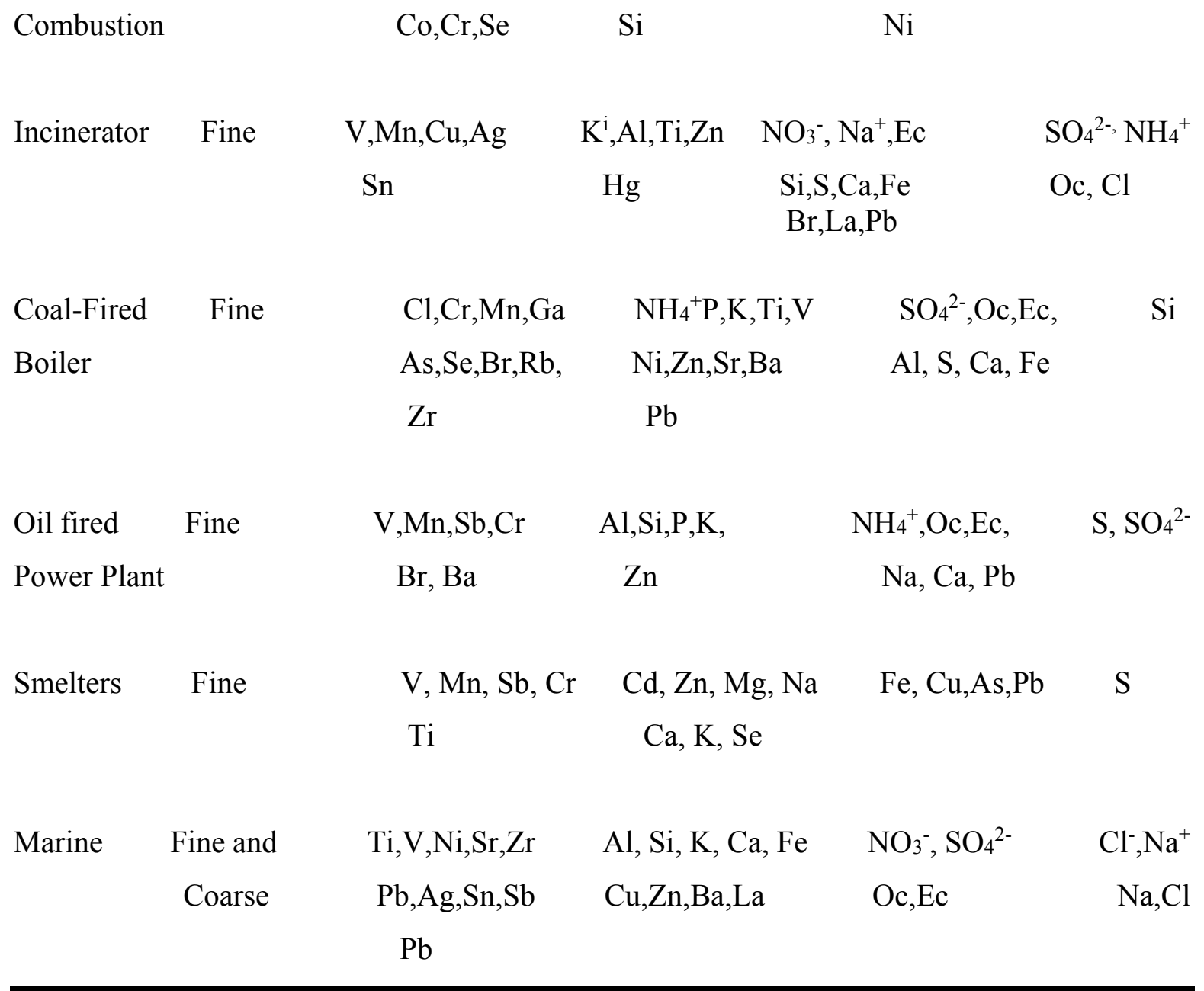

Source: Chow (1995), Johnson et al. (2011), Reid et al. (2013).

Of source that emits primarily carbonaceous particles, then the use of organic compounds markers would be necessary. Tables 4 depict the elements ions, carbon, and possible sources. 


\section{Analytical technique for ambient and source samples}

The common methods of analysis used in top-down source apportionment are in Table 4.

Table 4: Methods of analysis utilized in Top-down source apportionment

\begin{tabular}{|c|c|}
\hline Parameters measured & Methods of analysis \\
\hline Particle mass & Gravimetric analysis, $\beta$-gauge monitoring \\
\hline Ions $\left(\mathrm{F}^{-}, \mathrm{Cl}^{-} \mathrm{No}_{2}{ }^{-}, \mathrm{PO}_{4}{ }^{3-} \mathrm{Br}\right.$ & Ion Chromatography or Automated \\
\hline $\mathrm{SO}_{4}{ }^{2-} \mathrm{No}_{3}{ }^{-}, \mathrm{K}^{+}, \mathrm{NH}_{4}{ }^{+}$ & Colorimetric analysis. \\
\hline Elements ( $\mathrm{Na}, \mathrm{Mg}, \mathrm{Al}, \mathrm{Si}, \mathrm{P}$, & XRF, PIXE, INAA, ICP, Emission Spectroscopy, \\
\hline $\mathrm{S}, \mathrm{Cl}, \mathrm{K}, \mathrm{Ca}, \mathrm{Ti}, \mathrm{V}, \mathrm{Cr}, \mathrm{Mn}, \mathrm{Fe}$ & AAS \\
\hline $\mathrm{Co}, \mathrm{Ni}, \mathrm{Cu}, \mathrm{Zn}, \mathrm{Ga}, \mathrm{As}, \mathrm{Se}, \mathrm{Br}$, & \\
\hline $\mathrm{Rb}, \mathrm{Y}, \mathrm{Sr}, \mathrm{Zr}, \mathrm{Mo}, \mathrm{Pd}, \mathrm{Ag}$ & \\
\hline $\mathrm{Cd}, \mathrm{In}, \mathrm{Sn}, \mathrm{Sb}, \mathrm{Ba}, \mathrm{La}, \mathrm{Au}, \mathrm{Hg}$ & \\
\hline $\mathrm{Ti}, \mathrm{Pb}$, and $\mathrm{U})$ & \\
\hline \multirow[t]{4}{*}{ Individual Organic Compounds } & Solvent extraction method \\
\hline & Gas Chromatography-mass spectrometer \\
\hline & (GC-MS), High performance Liquid \\
\hline & Chromatography (HPLC). \\
\hline Total Carbon Elemental Carbon & Thermal manganese Oxidation method, \\
\hline Organic Carbon, Carbonate & Thermal Optical resistance of Thermal Optical \\
\hline Carbon, Thermal Carbon Fractions & Transmission method \\
\hline Total Carbon & Thermal combustion method \\
\hline Absorbance (Light absorbing & Optical absorption transmission \\
\hline \multirow[t]{2}{*}{ Carbon) } & Densitometry, Integrating plate \\
\hline & or integrating sphere method. \\
\hline
\end{tabular}

Source: Chow, (1995), Xu et al. (2013).

INAA - Inductive Neutron Activation Analysis, ICP - Inductively coupled plasma, AAS - Atomic Absorption Spectrophotometer, XRF - X-ray Fluorescence, PIXE - Proton Induced X-ray Emissions 


\section{REFERECENCES}

Bellis C.A, Larsen B.R, Amato F, El - Haddad I, Farez O, Harrison R.M, Hopke P.K, Nava S, Paatero P, Prevot A, Quass U, Vecchi R, Viana M. (2014). European guide On air pollution source apportionment with receptor models. JRC Reference Reports: Luxembourg: Publications Office of the European Union. Doi:10.2788/9307.

Chow J.C (1995). Critical review: Measurement methods to determine compliance of ambient air quality standards for suspended particles. J. Air \& Waste Management Association. 45: $320-385$.

Fawole O.G, Olofinjana B., Owoade O.K (2016). Compositional and air-mass tragectory analysis of a heavy dust episode (HDE) aerosols in Ile-Ife, Nigeria. British J. Appl. Sci.\& Tech. 13(1):1-15.

Chowdhury Z, Elizabeth A, Cohen A., Brauer MC (2009): Current Source apportionment studies In Asia: An overview. San Diego State University, Environmental Health Graduate School of Public Health.

Guttikunda S (2008): What is particulate matter? Simple Interactive models for Better Air Quality. SIM - air working paper series: 10 - 2008.www.sim-air.org

Guttikunda S. (2011). Top-Down, Bottom-up source apportionment. A primer on source apportionment. www.urbanemissions.info.

Harrison R.M, Stedman J. Derrent D (2008): New Directives: Why are PM10 concentrations in Europe. Not falling? Atmospheric Environ. 42: 603-606.

Health Effects Institute (2004). Health effects of outdoor air pollution in developing countries of Asia: A literature review. Special Report 15. www.healtheffects.org

Johnson T.M. Guttikunda S. Wells G.J. Artaxo P Bond TC, Russell A.G, Watson J.G., West J (2011). Tools for Improving air quality management. A review of Top-down source Apportionment techniques and their application in developing countries. ESMAP Formal Report 339/11.

Khan, Md Firoz, Latif M. T., Amil, N., Juneng, L., Mohamad, N., Nadziri, M. S. M. Hoque, H. M. S. (2015). Characterization and source apportionment of particle number concentration at a semi-urban tropical environment. Environ Sci Pollut Res. DOI 10.1007/s11356-015-4541-4. 
Morales Betancourt R, Nenes A (2014). Understanding the contributions of aerosol properties and parameterization discrepancies to droplet number variability in a global climate model. Atmos Chem Phys 14: 4809-4826.

Owoade K.O., Hopke P.K, Olize F.S., Adewole O.O, Ogundele L.T., Fawole O.G (2016). Source apportionment analyses for fire $\left(\mathrm{PM}_{2.5}\right)$ and coarse $\left(\mathrm{PM}_{2.5}-10\right)$ mode particulate matter (PM) measured in an urban area in southwestern, Nigeria. Atm.Poll.Res. Pp $1-15$.

Pope C.A., Dockery D.W (2006). Health effect of fine particulate air pollution. Lines that connect. Journal of the Air Waste Management Association. 56 (6): 709- 742.

Reid JS, Hyer EJ, Johnson RS, Holben BN, Yokelson RJ, Zhang J, Campbell JR, Christopher SA, Di Girolamo L, Giglio L, Holz RE, Kearney C,Miettinen J, Reid EA, Turk FJ,Wang J, Xian P, Zhao G, Balasubramanian R, Chew BN, Janjai S, Lagrosas N, Lestari P, Lin N-H, Mahmud M, Nguyen AX, Norris B, Oanh NTK, Oo M, Salinas SV, Welton EJ, Liew SC (2013). Observing and understanding the Southeast Asian aerosol system by remote sensing: an initial review and analysis for the Seven Southeast Asian Studies (7SEAS) program. Atmos Res 122:403-468.

Xu J, Wang Z, Yu G, Sun W, Qin X, Ren J, Qin D (2013). Seasonal and diurnal variations in aerosol concentrations at a high-altitude site on the northern boundary of QinghaiXizang Plateau. Atmos Res 120-121:240-248.

(C) 2017 by the authors. Licensee Preprints, Basel, Switzerland. This article is an open access article distributed under the terms and conditions of the Creative Commons by Attribution (CC-BY) license (http://creativecommons.org/licenses/by/4.0/). 